\title{
THE ECOLOGY AND CONTROL OF BARLEY GRASS : A REVIEW
}

\author{
D. A. GRANT \\ Grasslands Division, DSIR, Palmerston North \\ P. J. RUMBALL \\ Research Division, Department of Agriculture, \\ Palmerston North
}

\section{Summary}

The review indicates the fragmentary and often conflicting nature of information on the ecology and management control of barley grass. Quantitative information derived under New Zealand conditions on the intenaction of soil, climate and management with the phenology and growth of barley grass is almost entirely lacking.

\section{INTRODUCTION}

BARLEY GRASS is the common name for wild Hordeum species found in New Zealand and Australian pastures. Of the eight species of Hordeum listed in Hitchcock (1950) only $H$. vulgare (cultivated barley) is of agronomic value. The rest all furnish forage when young but many species are aggressive weeds and some at maturity are injurious to stock. Such species usually behave as annuals, frequently inhabiting disturbed and/or drought-prone sites. In this country the most frequent is $H$. murinum (Allan, 1940; Meeklah, 1964) others of more restricted distribution being $H$. marinum Huds., $H$. jubatum (Allan, 1940) and H. hystrix (Meeklah, 1964). H. leporinum (formerly H. murinum (Willis, 1962)) is the common species in Australia (Smith, 1968a).

In New Zealand, barley grass is regarded as a serious weed because of its relative unpalatability when mature and the lamb pelt and wool damage resulting from the sharp awned seed (Saxby, 1956). Although it was first recorded in Otago in 1864 (Hooker, quoted by Allan, 1940) and the damaging effect of the seed on sheep's wool was mentioned by Allan (1936) it was not until the 1950s that the plant became a serious problem in New Zealand. Loughnan (1964) showed that the percentage of lamb pelts down-graded in three Canterbury freezing works largely as a result of barley grass seed damage had increased from $0.08 \%$ in 1953 to $21.9 \%$ in 1963 . Most of this increase occurred in the early 1960 s and since that time there has been little change (Rumball, 1970). The present national cost in terms of pelts down-graded because of seed damage is estimated at $\$ 500,000$ (Rumball, 1970). To this must be added the unknown cost of control measures used.

Although regarded as a weed in many situations in Australia, barley grass is rated by Smith (1968b) as a useful forage species in the annual pasture zone. Under conditions adverse to accepted pasture plants, the large seed allows rapid germination and establishment and the plant 
recovers rapidly from defoliation. In semi-arid pastoral country, barley grass is preferentially grazed by sheep in the winter/spring period and forms a major component of the animals' diet at this time (Leigh and Mulham, 1966).

Although many observations have been made, quantitative information on the ecology of such an important weed and/or forage species is almost completely lacking in New Zealand. Some work on interactions with pasture management and basic aspects of the life-cycle has been conducted in Australia and will be drawn on for this review, but by and large the material quoted is of a subjective nature. Apart from the following section, no attempt is made to differentiate between Hordeum species in the text, but information derives principally from $H$. murinum and H. leporinum.

\section{TAXONOMY}

Descriptions of the barley grass species mentioned previously ( $H$. murinum, $H$. marinum, $H$. hystrix and $H$. leporinum) are given by Allan (1540), Hubbard (1954), Morrison (1958) and Willis (1962).

Hordeum murinum, $H$. leporinum, $H$. glaucum and a hexaploid murinum tvpe form the murinum complex, a group characterized by morphological similarity and taxonomic confusion (Morrison, 1958). Previously $H$. leporinum was regarded as a tetraploid and $H$. murinum as a diploid (Covas, 1949; Hubbard, 1954) but cytological evidence presented by Rajhathy and Morrison (1962) indicates that although extreme types differ slightly in awning characteristics both $H$. murinum and $H$. leporinum are tetraploid and conspecific. Hordeum leporinum types are more restricted to the Mediterranean which is probably the centre of origin of both (Rajhathy and Morrison, 1962).

\section{DISTRIBUTION}

Barley grass is ubiquitous, being common to most of Europe and West Asia, North and South America, Australia and New Zealand (Rajhathy and Morrison, 1962; Willis, 1962), but is not everywhere an agricultural problem (Davison, 1970).

A positive relationship in Great Britain between the distribution of barley grass and decreasing rainfall/increasing temperature has recently been shown (Davison, 1970).

In New Zealand the plant is found on soils of medium to high fertility, especially in sheep farming areas subject to frequent dry summers (Saxby, 1956; Glue and Matthews, 1958) - in particular Hawke's Bay, NelsonMarlborough, Canterbury and Otago (Loughnan, 1964; Rumball, 1970) Within farms, barley grass is most frequent on areas of severe disturbance - e.g., under shelterbelts, in sheep yards, on stock camps and along fence lines (Meeklah, 1964; Leonard, 1965). In Otago, barley grass occurs within the pasture itself only in the more arid areas (Meeklah, 1964). In the generally harsher Australian environment, barley grass may be present in the pasture as a few scattered plants or it may dominate. Also the one pasture may have a very different content from year to year (Smith, 1968a). 


\section{SEED PRODUCTION, GERMINATION AND ESTABLISHMENT}

Barley grass is characterized by early seasonal maturity and copious seed production, up to $2,000 \mathrm{lb}$ of seed per acre having been recorded in Australia (Smith, 1968a). The seed is large in comparison with the seed of many other grasses, there being from 73,000 to 160,000 seeds per pound (Smith, 1968a).

Seed may be set as early as mid-late October in New Zealand (Cassels, 1966).

Harris $(1959,1961)$ found no dormancy in freshly matured seed, $90 \%$ germination occurring within two weeks. In contrast, Australian produced seed can exhibit considerable dormancy (Laude, 1956; Rossiter, 1966; Smith, 1968a; McGowan, 1970). Inhibitory substances (Waisel and Adler, 1959) and high temperature effects (Smith, 1968a) have been suggested. Smith (1968a) suggests germination is affected in a complex way by interactions of temperature and moisture in summer and day and night temperatures in autumn.

Viable barley grass seeds on or within half an inch of the soil surface can occur in large numbers. Meeklah (1964) has recorded up to 4,000 seed/sq. ft in autumn on the Maniototo Plain. Harris (1959) found viability dropped from $90 \%$ at seed shed to $40 \%$ in July; practically all seed having disappeared by the following November. Similar results were recorded by Meeklah (1966). However, Cassels (1966) suggested severe re-infestations could occur from spring germinations of seed carried over winter even though viability might be low.

\section{COMPETITIVE ABILITY}

Saxby (1956) was of the opinion that there are few useful plants that can successfully compete with barley grass where it is strongly established. Barley grass is more competitive for moisture under limiting conditions than subterranean clover (Trifolium subterranean) (Smith, 1968c), and more successful at high $\mathrm{N}$ and $\mathrm{Ca}$ levels than other annual grass components of the pasture (Moore, 1966). However Smith (1968b) found no significant advantage to barley grass over the annual Wimmera ryegrass (Lolium rigidum) under high $\mathrm{N}$ and non-limiting moisture, although he found that barley grass had faster seedling growth and a superior capacity to recover from defoliation.

From studies of species composition, Grant and Ball (1970) found that barley grass communities contained fewer species than the surrounding pasture which suggests competitive exclusion. It is interesting to note also that there was a positive correlation between the frequencies of occurrence of barley grass and ryegrass, suggesting that the latter was no less competitive than barley grass.

\section{THE INFLUENCE OF SOIL}

Increases in barley grass have long been thought to be associated with increased soil fertility, particularly increased soil $\mathrm{N}$ levels (Meadley, 1946; Crocker and Tiver, 1948; Tiver and Crocker, 1951; Saxby, 1956; Glue and Matthews, 1958; Moore, 1965). Grant and Ball (1970) demonstrated that frequencies of barley grass plants were positively correlated with levels of available soil N. Raising soil fertility by fertilizer application, legume oversowing and increasing stocking rates enables barley grass to make rapid growth from the seedling stage and compete against 
species already present during the moist winter-spring period (Saxby, 1956; Moore, 1965). High soil $\mathrm{N}$ conditions may also reduce frost damage to barley grass (Smith, 1968b).

Other factors could also be involved. For example, Rossiter (1964) found the presence of barley grass to be associated with high soil phosphate status, and Grant and Ball (1970) found soil salinity levels higher under barley grass communities than surrounding pasture.

\section{THE INFLUENCE OF CLIMATE}

By opening up the existing sward, seasonal drought favours barley grass establishment from seed (Saxby, 1956). Because of the early maturity of barley grass, seed can then be set by the onset of the next dry spell.

In Australia, the amount and timing of autumn rain at the end of the dry period have a big effect on the degree of barley grass infestation (Meadley, 1946; Tiver and Crocker, 1951; Tiver, 1954). Early light rain or late rain when temperatures have dropped increases subterranean clover seedling mortality and/or reduces growth without affecting barley grass and other weeds to the same extent.

Barley grass is susceptible to frost damage, this being more severe when the growth is rank (Smith, 1968b). However, cold conditions can have a positive influence on survival of the species by causing earlier production of seed-heads in the following season (Smith, 1968b).

\section{THE INFLUENCE OF MANAGEMENT}

Levy (1948) claimed that the increase in stock numbers resulting from fertilizer application and introduction of clovers on dry hill country caused overcrowding on stock camps with subsequent death of the pasture, so creating an ideal environment for annuals such as barley grass.

However, on well fertilized flat to rolling land, Gunning (1966) found that, once present, barley grass was more likely to be a serious problem on under-stocked farms. Increased stocking rate, a fall in the ratio of cattle to sheep, or a change from fat to store stock, particularly with cattle, were thought to be associated with a fall in barley grass content.

Regular hard grazings have been found to increase production of barley grass green herbage, particularly in the late spring. The removal of flowering shoots from plants approaching maturity causes the formation of new tillers (Robards and Leigh, 1967).

Harvesting operations, by allowing prolific seeding and leaving an open pasture, are thought to favour the spread of barley grass (Saxby, 1956).

\section{CONTROL}

Many methods have been advocated but few seem to have achieved widespread success. Fencing off affected areas and applying special management has been suggested (Levy, 1948). Barley grass can perhaps be eradicated by stocking very heavily in winter and spring. This weakens the plant during its period of active growth. Further heavy stocking in late spring and summer may prevent seed-heads from forming (Gunning, 1966; George, 1968). George (1968) also found that there was no problem from barley grass at low stocking rates, possibly because of competition effects on germination and seedling growth. Smith (1968d) found 
total control of barley grass was not possible under different set-grazing intensities and mowing practices over two seasons. Continuous heavy grazing increased the proportion of barley grass in dry matter production. More seeds were produced at an intermediate grazing intensity than at a low or high one. Similarly, Burt (1966) found that regular and severe grazings did not reduce the number of fertile seed-heads but did delay flowering and the plants eventually flowered much closer to the ground. Morley et al. (1969) found that barley grass abundance was reduced by rotational grazing with sheep compared with set-stocking but that stocking rate had no effect. A knowledge of differential germination patterns and seedling palatability has made it possible to control barley grass effectively in irrigated subterranean clover (Trifolium subterraneum)Wimmera ryegrass pastures of Australia by deferring grazing for 20 days following irrigation and then set-stocking at a heavy rate. At this stage, the barley grass, having germinated completely, is more palatable than subterranean clover seedlings and is eaten out (Myers and Squires, 1970).

Mowing before seed-head maturity has been a recommended control measure in Australia in the past (Tiver, 1954) but it has not been favoured in the Waikato (Boyer, 1961). Smith (1968d) found that mowing with removal of cuttings reduced the proportion of barley grass in the pasture but did not give complete control.

Suppression of barley grass by oversowing high producing useful annuals such as barley, oats (Avena sativa) or Westerwolds ryegrass ( $L$. multiflorum) in areas badly infested or liable to infestation was first suggested by Levy (1948) and subsequently by Loughnan (1964) and Leonard (1965). In Australian annual legume pastures, establishment of perennial grasses to increase the stability is recommended as a means of reducing the potential of invasion by barley grass (Tiver, 1954). Where the infestation is heavy, cropping is apparently an effective means of control (Thompson, 1962).

Although not to be discussed in this paper, most efforts in barley grass control are based on the use of chemicals. Recommendations depend on the premise that, as barley grass is an annual with a limited seed life in the soil, prevention of seed formation should result in eradication (Leonard, 1965). However, this has been difficult to achieve in practice, especially in mixed grass-legume pastures.

Whatever method of control is used in the different situations and pastures where barley grass occurs, long-term success depends among other things on improving the vigour of the pasture through oversowing, fertilization, improved stocking practice, control of pests and diseases (Tiver, 1954; Glue and Matthews, 1958) and removal of all sources of reinfestation from the farm (Meeklah, 1964, 1966).

\section{CONCLUSION}

There is as yet no simple universal method of controlling barley grass. The information reviewed here is often conflicting, particularly in relation to the effect of grazing methods and intensities on barley grass control. Some of this conflict may be due to the influence of environmental differences in different experiments. Also much of the information derives from experiments aimed at studying other problems, or is based on observation.

To avoid the expense of repeating the chemical control process every few years, much more quantitative information is required from specific 
studies under New Zealand conditions on aspects such as the phenology and growth pattern of barley grass and how this is affected by soil, climatic factors and management practices (e.g., grazing frequency and intensity). The effect of these practices on the susceptibility of pasture to invasion also must be examined. In particular, areas of extreme disturbance - e.g., stock camps - should be studied under various methods of stocking.

The place of useful special-purpose plants in areas most susceptible to barley grass invasion, although suggested at various times, has yet to be investigated.

If the ecological system as a whole is ignored, chemical treatment for barley grass control tends to create a void which is rapidly filled by other weeds such as storksbill (Erodium cicutarium).

Finally, we should not forget that the plant may provide valuable animal feed at times of the year when pasture growth is minimal. One aim could be to remove the undesirable aspects of the species through plant breeding and then exploit the species to the full.

\section{REFERENCES}

Allan, H. H., 1936: Bull. N.Z. Dep. scient. ind. Res. 49. 1940: Bull. N.Z. Dep. scient. ind. Res. 83.

Boyer, M. G., 1961: Proc. 14th N.Z. Weed Control Conf.: 121.

Burt, R. L., 1966: CSIRO Divn. Pl. Indust. Field Stn. Record 5: 1.

Cassels, G. R., 1966: Proc. 19th N.Z. Weed \& Pest Control Conf.: 110.

Covas, G., 1949: Madrono, 10: 1.

Crocker, R. W.; Tiver, N. S., 1948: J. Br. Grassld Soc., 3: 1.

Davison, A. W., 1970: J. Ecol., 58: 453.

George, J. M., 1968: CSIRO Anim. Phys. Ann. Rep. 1967-68: 56.

Glue, D. I.; Matthews, L. J., 1958: N.Z. Il Agric., 97: 313.

Grant, D. A.; Ball, P. R., 1970: Proc. 23rd N.Z. Weed \& Pest Control Conf.: 83

Gunning, B. A., 1966: Proc. 19th N.Z. Weed \& Pest Control Conf.: 127.

Harris, G. S., 1959: Proc. 12th N.Z. Weed Control Conf.: 85. 1961: N.Z. Jl agric. Res., 4: 253.

Hitchcock, A. S., 1950: USDA Misc. Publ. 200.

Hope, A., 1964: N.Z. Dairy Exporter, 40: 4.

Hubbarb, C. E., 1954: Grasses. Penguin Books, Middlesex. 428 pp.

Laude, H. M., 1956: J. Range Mgmt, 9: 126.

Leigh, J. H.; Mulham, W. E., 1966: Aust. J. exp. Agric. Anim. Hus., 6: 460.

Leonard, W. F., 1964: Proc. 17th N.Z. Weed \& Pest Control Conf.: 33. 1965: Proc. 15th Lincoln Fmrs' Conf.: 112.

Levy, E. B., 1948: Sheepfmg A.: 69.

Loughnan, R. J. M., 1964: Proc. 17th N.Z. Weed \& Pest Control Conf.: 40. McGowan, A. A., 1970: Aust. J. exp. Agric. Anim. Hus., 10: 401.

Meadley, G. R. W., 1946: J. Dep. Agric. W. Aust., 23: 85.

Meeklah, F. A., 1964: Proc. 17th N.Z. Weed \& Pest Control Conf.: 28. 1966: Proc. 19th N.Z. Weed \& Pest Control Conf.: 113.

Moore, R. M., 1965: Proc. 9th int. Grassld Congr.: 429. 1966: Proc. ecol. Soc. Aust., 1: 106.

Morley, F. H. W.; Bennett, D.; McKinney, G. T., 1969: Aust. J. exp. Agric. Anim. Hus., 9: 74.

Morrison, J. W., 1958: Acta. bot. neerl., 7: 654. 
Myers, L. F.; Squires, V. R., 1970: Aust. J. exp. Agric. Anim. Hus., 10: 151

Rajhathy, T.; Morrison, J. W., 1962: Can. J. Genet. Cytol., 4 (2) : 240.

Robards, G. E.; Leigh, J. H., 1967: Aust. J. exp. Agric. Anim. Hus., 7: 528.

Rossiter, R. C., 1964: Aust. J. agric. Res., 15: 61.

- 1906: Adv. in Agron., 18: 156.

Rumball, P. J., 1970: Proc. 23rd N.Z. Weed \& Pest Control Conf.: 77.

Saxby, S. H., 1956: Bull. N.Z. Dep. Agric. 250.

Smith, D. F., 1968a: Aust. J. exp. Agric. Anim. Hus., 8: 478.

1968b: Ibid., 8: 484.

1968c: Ibid., 8: 702 .

1968d: Ibid., 8: 706

Tiver, N. S., 1954: J. Dep. Agric., S. Aust., 58: 49.

Tiver, N. S.; Crocker, R. W., 1951: J. Br. Grassld Soc., 6: 29.

Thompson, F. B., 1962: N.Z. Jl Agric., 105: 353.

Waisel, Y.; Adler, Y., 1959: Can. J. Bot., 37: 741.

Willis, J. H., 1962: A Handbook to Plants in Victoria, Vol. 1. Melbourne University Press. 